\title{
Urgensi Mengembangkan Literasi Informasi dan Literasi Budaya Pada Anak Usia Dini
}

\author{
Purwanto Putra ${ }^{1}$, Renti Oktaria ${ }^{2}$ \\ ${ }^{1}$ Prodi D3 Perpustakaan, Universitas Lampung \\ ${ }^{2}$ Prodi PG-PAUD, Universitas Lampung \\ Jl. Prof. Dr. Sumantri Brojonegoro No 1 Bandar Lampung \\ E-mail: purwanto.putra@fisip.unila.ac.id
}

\begin{tabular}{l} 
Article Info \\
\hline Received September 2020 \\
Accepted Oktober 2020 \\
Published Oktober 2020
\end{tabular}

Keywords:

information literacy,

cultural literacy, early

childhood, early

childhood Education.

\begin{abstract}
This study discusses the urgency of developing Information Literacy and Cultural Literacy in Early Childhood in the context of the application of the National Literacy Movement. The purpose of this paper is to photograph the concept and the extent of the urgency of the introduction of information literacy skills and cultural literacy in early childhood in supporting the application of the National Literacy Movement. Review the role and internalization of daily activities and teaching and learning activities in the classroom in the context of information literacy and cultural literacy. This research uses a qualitative research approach with literature study design and conceptual analysis. The results of this study indicate that there is a need for early childhood recognition and planting in relation to the ability of information literacy and cultural literacy in responding to the development of global society and multiculturalism. From this study it was also revealed that there was a need and attention from stakeholders to facilitate and reduce the concept of information literacy and cultural literacy for young children in a more complete grand design and technical implementation in the community and schools.
\end{abstract}

\begin{abstract}
Abstrak : Penelitian ini membahas tentang urgensi pengembangkan Literasi Informasi dan Literasi Budaya pada Anak Usia Dini dalam konteks penerapan Gerakan Literasi Nasional. Tujuan dari tulisan ini adalah untuk memotret konsep serta sejauh mana urgensi diterapkannya pengenalan kecakapan literasi Informasi dan literasi Budaya pada anak usia dini dalam mendukung penerapan Gerakan Literasi Nasional. Mengkaji peran dan internalisai kegiatannya sehari-hari dan proses belajar mengajar di kelas dalam konteks kemampuan literasi informasi dan literasi budaya. Penelitian ini menggunakan pendekatan kualitatif dengan desain studi pustaka dan analisis konseptual. Hasil penelitian ini menunjukkan bahwa ada kebutuhan pengenalan dan penanaman sedini mungkin bagi anak usia dini terkait kemampuan literasi informasi dan literasi budaya dalam merespon perkembangan masyarakat global dan multikulturalisme. Dari penelitian ini juga terungkap bahwa ada kebutuhan dan atensi dari para pemangku kepentingan untuk memfasilitasi dan menurunkan konsep literasi informasi dan literasi budaya bagi anak usia dini dalam grand design yang lebih lengkap serta teknis pengimlementasian dimasyarat dan sekolah.
\end{abstract}

Kata kunci : literasi informasi, literasi budaya, anak usia dini, pendidikan anak usia dini. 


\section{PENDAHULUAN}

Kian hari dunia terlihat semakin mengecil, dalam kiasan bahwa penetrasi internet dengan berbagai perangkat dan saluran komunikasi digital telah menyatu dengan semua orang dari berbagai komunitas dunia. Berbagai bentuk intekrasi dalam konteks bisnis, pendidikidan termasuk budaya menjadi saling terhubung dan bercampur. Kondisi ini sebagaimana juga yang terjadi di Indonesia. Data hasil survei yang pernah disampaikan Asosiasi Penyelenggara Jaringan Internet Indonesia (APJII) tahun 2016 melaporkan bahwa pengguna internet di Indonesia. Dari total penduduk Indonesia, yang berjumlah 256,2 juta orang sudah 132,7 juta orang yang terhubung ke Internet. Maka dapat dikatakan bahwa lebih dari setengah penduduk Indonesia telah menggunakan Internet. Jumlah ini akan terus mengalami kenaikan hingga sekarang ini. Kenaikan tersebut ditengarai dipicu oleh perkembangan infrastruktur telekomunikasi dan mudahnya mendapatkan gawai dan telepon pintar (Fairus, Naibaho, Monohevita, Aries, \& Pawoko, 2017).

Pada lingkup geografis dan sosial baik itu pada konteks komunitas lokal, masyarakat pedesaan dan perkotaan juga seiring sejalan tumbuh menjadi masyarakat budaya yang lebih beragam. Keragaman budaya dan informasi dalam masyarakat Indonesia semakin bertumbuh dan berkembang untuk kemudian menjadi identitas multikultural masyarakat Indonesia yang semakin majemuk, selain dalam dimensi Nasional juga Internasional.

Kebutuhan akan kecakapan literasi informasi pada anak dimasa sekarang ini memiliki urgensi untuk diterapkan sedini mungkin. Kondisi konkritnya sudah begitu jamak kita temui misalnya pada masa pandemi Covid-19 yang telah berbulan-bulan hingga sekarang belum diketahui kapan akan mereda. Kondisi pada anak yang hingga saat ini masih dirumahkan, maksudnya harus melaksanakan proses belajar dan mengajar dari rumah. Dengan beraneka rupa kegagapan, orang tua, keluarga dan masyarakat dengan menggunakan perantara TIK mesti mendukung terselenggaranya proses belajar mengajar.

Literasi informasi atau keberaksaraan informasi sangat penting karena anak-anak kita dikelilingi oleh lautan informasi yang semakin berkembang dalam berbagai format khususnya yang berada pada kanal atau media internet. Tidak semua informasi diciptakan sama, beberapa informasi memiliki otoritas 
yang jelas dapat diandalkan tetapi beberapa bisa menyesatkan dan palsu. Jumlah informasi yang tersedia akan terus meningkat pada setiap detiknya. Jenis teknologi yang digunakan untuk mengakses, memanipulasi, dan membuat informasi juga berkembang sehingga akan terjadi yang dinamakan kebanjiran informasi. Hal tersebut membuat kita bingung untuk memilih mana informasi yang tepat untuk kita. Dengan demikian, kita sangat membutuhkan literasi informasi.

Dari kondisi tersebut kita dapat berfikir ulang dan secara lebih mendalam melihat bahwa benar ada urgensi bagi anak termasuk anak usia dini untuk mendorong mereka belajar semandiri mungkin. Itu artinya segala pemahaman dan kegiatan yang dilakukan anak harus disandarkan atas dasar pemerolehan informasi mereka, baik yang diapatkan melalui pendampingan atau secara mandiri.

Berkenaan dengan kebutuhan informasi anak, sudah begitu banyak yang diketengahkan dari berbagai hasi penelitian sudah terbukti bahwa kebutuhan informasi tersebut ada pada kategori tinggi dan secara berkesinambungan sesuai dengan atau mengikuti perkembangan umurnya. Rasa ingin tahu anak dapat dibuktikan dengan kebiasaan anak umumnya selalu banyak bertanya mengenai berbagai hal. Pada masa awal perkembangan anak akan mulai bertanya kepada orang tua, kemudian keluarga dan bahkan masyarakat yang berada disekitar lingkungannya. Maka dari itu penting agar kebutuhan informasi anak dapat dipenuhi secara menyeluruh dan utuh.

Selain menyoal literasi informasi ada pula pilihan kecapakan lain yang perlu diperkenalkan pada anak sejak sedini mungkin yaitu literasi budaya. Literasi budaya dapat diinterpretasi sebagai kemampuan untuk memahami, berinteraksi, dan berkolaborasi lintas budaya yang berbeda-beda. Literasi budaya menjadi kebutuhan yang cukup krusial untuk turut dikembangkan melengkapi kecakapan literasi informasi. Kedua jenis kecapakan literasi ini dibutuhkan dan mesti dikuasai oleh anak dalam lingkungan kecakapan hidup di abad ke-21.

Selain itu dampak dari pergeseran menuju komunitas global yang semakin dekat dengan kondisi Indonesia. Anak-anak di negeri ini dalam waktu beberapa tahun ke depan, generasi emas Indonesia, akan berhadapan langsung dengan situasi keterbukaan masyarakat global yang akan berimplikasi 
keberbagai sendi-sendi kehidupan bermasyarakat dan berbangsa. Maka dari itu kurikulum pendidikan dan para pendidik di Indonesia juga mesti membantu dan memfasilitasi para siswa agar dapat menjadi warga global yang kompetitif dan inovatif dengan menguasai berbagai kecakapan literasi.

Pada waktunya nanti telah diprediksi bahwa ada potensi kolaboratif antara unsur manusia dengan unsur teknologi digital yang kian hari menjadi semakin berkembang dan terbuka. Oleh karena itu harus ada strategi mengkombinasikan metode pengajaran yang inovatif dengan pembelajaran mandiri berbekal kecakapan literasi informasi dan literasi budaya. Harapannya kelak ini sekaligus menjadi upaya untuk menjadikan para siswa kita yang dimulai dari anak usia dini untuk menjadi pemimpin masa depan atau paling tidak menjadi pemimpin bagi dirinya masing-masing. Suatu upaya yang perlu dan mesti dikedepankan.

Dalam rangka memetakan dan menggali kebutuhan tersebut maka penelitian terkait urgensi kecakapan literasi informasi dan literasi budaya ini coba diketangahkan untuk mendapat masukan yang lebih komprehensif dari para akademisi dan praktisi di bidang pendidikan, literasi dan yang bergerak pada bidang budaya. Upaya penanaman nilai-nilai literasi informasi dan literasi budaya memang membutuhkan sinergisitas dari berbagai pihak. Melalui serangkaian uji coba demi menghasilkan konsep dan praktik pembelajaran yang tepat guna, kelas kolaboratif untuk mendukung proses belajar mengajar. Ini harus sesegera mungkin diupayakan agar segala potensi pengembangan inovasi yang berbasis teknologi dan informasi dapat segera diserap dalam lingkup bidang pendidikan, khususnya pendidikan literasi informasi dan literasi budaya bagi anak usia dini.

\section{METODE}

Penelitian yang digunakan adalah penelitian kualitatif. Jenis Pendekatan dari penelitian kualitatif yang digunakan adalah dengan pendekatan deskriptif kualitatif dimana data yang didapatkan adalah berasal dari pelaksanaan kegiatan pembelajaran dengan menggunakan metode ini untuk melihat sejauh mana urgensi pengembangan literasi informasi dan literasi budaya pada anak usia dini. Subyek yang digunakan dalam penelitian ini adalah analisis pustaka berkenaan dengan tema dan persoalan yang 
diajukan. Teknik pengumpulan data yang digunakan adalah dengan menggunakan kajian pustaka dan observasi digital dari sumber-sumber yang ada diberbagai pangkalan data online atau elektronis. Dalam penelitian kualitatif ada beragam metode analisis data yang dapat digunakan. Uji keabsahan data untukpenelitian ini didasarkan dengan empat kriteria yaitu derajat kepercayaan (uji credibility), Keteralihan (Uji Transferability), kebergantungan (dependability) dan kepastian (confirmability). Proses analisis data dilakukan dengan menggunakan model analisis interaktif (Huberman \& Miles, 2002).

\section{HASIL DAN PEMBAHASAN}

Hasil berisi jawaban dari permasalahan penelitian secara kuantitatif dan/atau kualitatif secara jelas, tepat dan lengkap. Hasil penelitian dapat dilengkapi dengan menggunakan informasi dalam bentuk gambar/grafik/tabel/uraian secara aktual. Pembahasan berisi ringkasan hasil penelitian, keterkaitan dengan konsep atau teori dan hasil penelitian lain yang relevan, menginterpretasikan penemuan secara logis (interpretasi temuan), menjelaskan keterbatasan penelitian, serta implikasinya terhadap perkembangan konsep atau keilmuan.

\section{Membangun Pengetahuan Berbasis Konsep Literasi Informasi}

Literasi informasi merupakan istilah serapan dan terjemahan dari bahasa asing, umumnya dikenal dengan kata information literacy. Sebelum kata literasi informasi digunakan dalam Bahasa Indoenesia, kata yang mewakili istilah ini dalam KBBI (Kamus Besar Bahasa Indonesia) yaitu melek huruf, kemelekan huruf (Pusat Bahasa Departemen Pendidikan Nasional, 2007). Sementara untuk kalangan pustakawan, yang biasa bergelut dengan konsep dan praktik ini menerjemahkannya dengan kata literasi. Walaupun seiring perkembangan kata literasi informasi telah dapat diterima sebagai bentuk umum untuk mendeskripsikan lingkup kajian ini. Memang ada timbul kesulitan manakala ingin menerjemahkan kata literate ini. Bukan hanya padanan dalam Bahasa Indonesia, kata literacy itu sendiri memang ada kesulitan tersendiri ketika akan diterjemahkan keberbagai bahasa lain seperti Bahasa Jerman, Prancis, Italia, Rusia, Turki, dan bahasa-bahasa lainnya. 
Secara sederhana literasi informasi dapat dipahami sebagai kemampuan untuk dapat menemukan, mengevaluasi, dan menggunakan informasi dalam berbagai jenis dan format. Berikut adalah pemetaan literasi informasi menurut (Sulistyo-Basuki, 2011) bahwa literasi informasi terbagi atas lima, intinya bahwa dari lima jenis literasi ini akan dapat menjadi bekal dan digunakan oleh anak dalam mendukung perkembangan anak kelima literasi tersebut yaitu, literasi visual, literasi media, literasi komputer, literasi jaringan, dan literasi kultural.

Dalam istilah yang lebih luas, sejarah penggunaan istilah literasi informasi mulai diperkenalkan untuk wilayah di negara-negara, Amerika Serikat, sekitar pertengahan tahun 1970an. Kondisinya tidak langsung ideal dan diterima oleh masyarakat luas. Secara pengertian dan landasan dasar literasi informasi ketika itu belum sepenuhnya dapat diterima oleh kalangan ilmuwan bidang informasi. Jikar merujuk pada penjelasan yang disampaikan oleh Shapiro dan Hughes (Hapiro \& Hughes, 1996) literasi informasi merupakan konsep yang sering digunakan namun memiliki sifat ambiguitas yang tinggi. Hal senada juga pernah diutarakan oleh Snavely dan Cooper (Snavely \& Cooper, 1997) yang mengatakan untuk dapat diterima oleh pemustaka atau orang-orang diluar bidang perpustakaan dan akademisi secara meluas. Maka pustakawan perlu bahkan berkewajiban untuk menjelaskan tentang definisi literasi informasi sekaligus untuk membedakannya dari instruksi bibliografis serta perbedaannya dari pendidikan dan pembelajaran pada umumnya. Namun ada pula pendapat yang menyanggah definisi-definisi yang masih dipertanyakan tersebut di atas, seperti pernyataan yang disampaikan Owusu-Ansah (Owusu-Ansah, 2005) ia berpendapat bahwa adanya banyak definisi dan konsep literasi informasi sesungguhnya tidakplah mencerminkan perbedaan atau ketidaksepakatan yang besar.

Menurut catatan sejarah istilah "information literacy" pertama kali dikemukakan oleh Paul Zurkowski yang mengatakan bahwa orang yang literat informasi adalah orang-orang yang terlatih dalam aplikasi sumberdaya dalam pekerjaannya (Behrens, 1994). Setelah itu barulah muncul definisi literasi informasi dari ANZIL yang merumuskan kesepakatan baru terkait definisi literasi informasi, kesepakatan itu dicapai pada tahun 2005 pada pertemuan IFLA, UNESCO dan National Forum for Information Literacy (NFIL) sebagai 
pertemuan tingkat tinggi di Bibliotheca Alexandriana di Alexandria, Mesir. Dari pertemuan tersebut barulah disepakati rumusan definisi literasi informasi

Information literacy encompasses knowledge of one's information concerns and needs, and the ability to identify, locate, evaluate, organize, and effectively create, use and communicate information to address issues or problems at hand; it is a prerequisite for participating effectively in the Information Society,and is part of the basic human right of life - long learning.

\section{Pengenalan Konsep Literasi Informasi Pada Anak Usia Dini}

Periode masa keemasan pertumbuhan anak usia dini yang berlangsung pada anak usia 0 hingga 8 tahun dalam rentang ini anak mulai mengenal dunia dan menentukan bagaimana akan tumbuh, berkembang, hidup dan beraktivitas dalam menjalani kehidupannya. Kecepatan pertumbuhan dan perkembangan yang sangat pesat dan bahkan mencapai 50 persen kapasitas kecerdasan manusia berlangsung pada kisaran usia 4 tahun, 80 persen pada usia 8 tahun, dan 100 persen-nya ketika anak mencapai usia 8 - 18 tahun (Riady, 2013). Maka dari itu dalam rentang usia tersebut merupakan usia rentan sekaligus usia dasar untuk perkembangan anak.

Pengenalan konsep dan kecakapan literasi informasi merupakan dasar bagi anak usia dini untuk melengkapi proses belajar anak pada fase belajar dengan meniru dan memahami dari apa yang dilihat dan dialami. Pada fase selanjutnya kecakapan literasi turut menjadikan anak tentang sumber informasi yang dapat diperolehnya sesuai dengan kebutuhannya secara lebih mandiri.

Pengenalan literasi informasi dengan sedini juga akan berimplikasi untuk memberikan pengetahuan awal dan akses kepada masing-masing anak usia dini untuk mulai untuk bersosialisasi, berpartisipasi dan pemenuhan sumber belajar kedepannya juga untuk meningkatkan kualitas dan kuantitas dalam mendukung kehidupannya kelak. Sehingga pada ujungnya adalah kemandirian dan kesadaran agar anak dapat memenuhi kebutuhan informasi, mengerti cara mendapatkan dan mengetahui secara menyeluruh tentang mana informasi yang kredibel, faktual dan terbebas dari hoax (berita bohong).

Sudah semestinya untuk menyongsong kecakapan abad 21 jika anak usia dini mulai dibekali atau dikembangkan kemampuan literasi informasinya. Hal yang juga harus dipahami orang tua atau pendidik bahwa pada fase 
perkembangan anak usia dini keterampilan literasi informasi dapat membantu dan mendukung anak agar berketerampilan dan kemampuan untuk mengidentifikasi, menemukan, mengevaluasi, menyusun dan secara efektif menciptakan pengetahuan baru, memanfaatkannya serta menkomunikasikan untuk pemecahan masalah atau pemenuhan informasi dan pengetahuan yang dibutuhkannya.

Cara penerapan literasi informasi bisa menjadi lebih aplikatif dan terstruktur dengan adanya pemodelan atau model literasi informasi. Adanya model memungkinkan untuk mengidentifikasi berbagai komponen serta menunjukkan hubungan antar komponen. Selain itu pemodelan dapat pula digunakan untuk menjelaskan apa yang di maksud dengan literasi informasi. Secara umum ada 4 model literasi informasi yang mayoritas digunakan yaitu The Big 6, Seven Pillars, dan Empowering 8 serta The Seven Faces of Information Literacy. Di antara 4 model tersebut memiliki kekhususan dan tujuannya masing-masing. Dalam konteks pendidikan dan pendidikan anak usia dini yang dianggap paling sesuai adalah The Big 6 .

The Big 6 pada awalnya dikembangkan di AS, pencetus sekaligus pengembangnya adalah dua orang pustakawan, Mike Eisdenberg dan Bob Berkowitz. The Big 6 menggunakan pendekatan pemecahan masalah untuk mengajar informasi dan keterampilan informasi serta teknologi. Model The Big 6 terdiri dari 6 tahap pemecahan masalah, pada masing-masing tahap dikelompokkan menjadi langkah-langkah atau komponen.

Tabel 1. Jumlah Sampel Berdasarkan Lokasi Penelitian dan Gender

\begin{tabular}{|c|c|c|}
\hline No & Tahapan & Komponen \\
\hline 1. & Definisi tugas & $\begin{array}{l}\text { - Definisikan masalah informasdi yang dihadapi } \\
\text { - Identifikasi informasi yang diperlukan }\end{array}$ \\
\hline 2. & $\begin{array}{l}\text { Strategi mencari } \\
\text { informasi }\end{array}$ & $\begin{array}{l}\text { - Menentukan semua sumber yang mungkin } \\
\text { - Memilih sumber terbaik }\end{array}$ \\
\hline 3. & Lokasi dan akses & $\begin{array}{l}\text { - Tentukan lokasi sumber secara intelektual maupun fisik } \\
\text { - Menemukan informasi dalam sumber }\end{array}$ \\
\hline 4. & $\begin{array}{l}\text { Menggunakan } \\
\text { informasi }\end{array}$ & $\begin{array}{l}\text { - Hadapi, misalnya membaca, mendengar, menyentuh, } \\
\text { mengalamati } \\
\text { - Ekstrak informasi yang relevan }\end{array}$ \\
\hline 5. & Sintesis & $\begin{array}{l}\text { - Mengorganisasikan dari banyak sumber } \\
\text { - Sajikan informasi } \\
\text { - Nilai proses, apakah efisien }\end{array}$ \\
\hline 6 & Evaluasi & $\begin{array}{l}\text { - Nilai produk yang dihasilkan dari segi efektivitas } \\
\text { - Nilai proses, apakah efisien }\end{array}$ \\
\hline
\end{tabular}




\section{Membangun Pengetahuan Berbasis Literasi Budaya}

Seorang tokoh di bidang literasi, E.D. Hirsch Jr ditengarai merupakan orang yang pertama kali mencetuskan istilah "literasi budaya" sekitar tahun 1987. Pada awalnya istilah tersebut digunakan untuk menjelaskan seperti juga orang yang melek huruf, fasih dalam membaca dan mampu menulis denggan baik, maka orang-orang yang melek budaya juga harus fasih dalam hal berkaitan dengan warisan budaya, sejarah, sastra, seni, politik dan hal-hal yang bersifat humaniora lainnya.

Salah satu karyanya yang dapat dikatakan fenomenal adalah tulisannya tentang daftar 5.000 fakta yang berkaitan dengan warisan Amerika -a list of 5,000 facts pertaining to American heritage- yang menurut Hirsch dan koleganya harus diketahui oleh setiap orang Amerika. Hingga saat ini karya ini masih menuai perdebatan sengit terkait tentang keabsahan nilai-nilai sejarah budaya yang basisnya lebih pada kelompok mayoritas - seperti perdebatan tentang manfaat pembelajaran tentang pengetahuan kontekstual yang melekat pada pembelajaran berbasis proses -process-based learning dibandingkan dengan pembelajaran atas nilai-nilai fakta secara sederhana, yang diwakili oleh daftar "esensial" tersebut.

Meskipun beberapa memiliki anggapan bahwa hal ini ruang lingkupnya masih terlalu sempit untuk dapat merepresentasi budaya secara asli dan holistik. Namun sejak masa itu konsep literasi budaya semakin berkembang dan dapat diterima untuk mewakili pemikiran dan pemahaman atas aspekaspek multikultural. Dalam konteks pembelajaran di kelas yang semakin terbuka dan modern, pengembangkan literasi budaya tidak berlebihan jika mesti dikatakan menjadi sangat penting. Hal mendasar yang mesti kita pahami dengan meningkatnya keragaman populasi siswa maka dibuutuhkanlah pemahaman dan apresiasi terhadap pengalaman, latar belakang, dan budaya dari masing-masing individu yang saling berbeda tersebut.

Literasi budaya akan turut membantu siswa dalam berinteraksi dan berkolaborasi secara efektif, begitu juga bagi anak usia dini yang sifatnya bisa berupa pengenalan sekaligus sebagai fondasi dasar. Pada praktinya kedua elemen tersebut akan menjadi keterampilan yang diperlukan dalam kehidupan mereka pada masa-masa perkembangan berikutnya. Menurut teori-teori pendidikan seperti Teori Perkembangan Sosial Vygotsky, pembelajaran terjadi 
dalam konteks sosial masyarakat. Dengan demikian, pemahaman yang lebih dalam tentang keanekaragaman dalam komunitas seseorang harus meningkatkan pembelajaran. Maka dapat diartikan bahwa bahwa keanekaragaman budaya dan multikulturalisme merupakan sumber daya yang dapat dimaksimalkan dalam konteks pendidikan berkaitan dengna budaya.

Para pendidik harus bisa mengembangkan lingkungan kelas yang dapat menumbuhkan literasi budaya. Salah satu pendekatan yang paling mendasar dan dapat diterapkan adalah dengan gagasan model pengajaran untuk membangun pengetahuan dan pengembangan ruang kelas kolaboratif.

Sebuah konsep membangun pengetahuan (co-constructing knowledge) secara sederhana, misalnya guru yang tidak lagi mengajar secara konvensional (peran tradisional guru sebagai orator) atau sebagai pusat pengetahuan dan pembelajaran. Sebaliknya, guru mesti menjadi pendukung yang berfokus untuk mengkontruksi dan menggali kemandirian belajar siswa, yang menjadikan segala masukan atau hasil konstruksi dari siswa, mengetahui secara detail apa yang dibutuhkan dan ingin diketahui siswa dalam proses pembelajaran. Dalam konteks ini perpustakaan, internet dengan perangkat literasi informasi merupakan sarana dan prasarana yang mesti ada.

\section{Pengenalan Konsep Literasi Budaya Pada Anak Usia Dini}

Model pembelajaran ini untuk konteks Indonesia sebenarnya sudah cukup populer, pembelajaran yang menjadikan guru sebagai fasilitator pembelajaran. Guru menyediakan alat belajar dan menawarkan instruksi dan saran sesuai kebutuhan siswa. Salah satu tugas utama guru juga adalah memastikan agar dalam setiap proses pembelajaran untuk membantu membangun motivasi siswa. Melalui metode ini, siswa akan tumbuh dalam suasana belajar yang nyaman dengan menggali berbagai wawasan dan kebutuhan yang dilakukan secara bersama-sama dengan teman-teman siswa. Sehingga ini secara langsung juga akan menumbuhkan pemahaman berbasis budaya yang berlansung pada kelompok dan alami. Hal yang akan menjadi tantangan selanjutnya adalah pada kemampuan masing-masing guru yang harus mencari cara untuk memenuhi standar pencapaian pembelajaran dengan mengakomodir berbagai improvisasi yang mengedepankan pendekatan yang kreatif dan interaktif. Harus ada kesepahaman antara guru dan siswa yang 
secara bersama-sama atas konstruksi standar yang seminimum mungkin mengorbankan nilai-nilai literasi budaya yang ingin dibangun.

Dalam konteks yang lebih praktis, konsep ini dapat diaplikasikan di ruang kelas kolaboratif yang secara alami mendorong konstruksi pengetahuan yang dibangun bersama yang difasilitasi dengan keterampilan literasi budaya. Kelas kolaboratif pada bisa saja akan menggeser konvensi lama terkait ruang dan pengajaran, sepert belajar tidak harus ada meja guru, pengaturan tempat duduk siswa, mengedepankan dialog berkelanjutan, diskusi dan pembelajaran yang dipimpin siswa. Guru menjadi sumber daya, berperan sebagai hub (penghubung) interaksi kelompok, dan memfasilitasi kebutuhan perangkat komunikasi dan strategi pembelajaran. Teknologi digital memungkinkan siswa untuk saling berinteraksi dengan ruang kelas lain di seluruh dunia dan saling berkolaborasi melalui proyek-proyek pembelajaran berbasis web dan aplikasi mobile. Dari ini maka semua elemen yang ada di dalam kelas akan turut mengambil peran dalam mempromosikan literasi budaya.

Keberhasilan siswa bergantung pada kemampuan mereka dalam berinteraksi secara positif dengan orang-orang dari latar belakang yang berbeda-beda. Di sini guru harus benar-benar bisa memainkan peran secara aktif dan memahami dan mengkalkulasi setiap perkembangan anak. Untuk jangka panjang ini sekaligus menjadi upaya untuk mempersiapkan siswa agar siap untuk jenjang pendidikan yang lebih tinggi atau saat berkarier dikemudian hari. Secara langsung ini juga akan berperan dalam meningkatkan keterampilan belajar akademik dan sosial para siswa.

\section{KESIMPULAN}

Literasi informasi merupakan kecakapan yang mengakomodasi pengetahuan dan kebutuhan informasi termasuk juga kemampuan untuk mengenali, mengetahui lokasi, mengevaluasi, mengorganisasi dan menciptakan, dan mengkomunikasikan informasi secara efektif dan efisien untuk mengatasi persoalan atau masalah yang dihadapi seseorang, termasuk bagi anak usia dini.

Kecakapan literasi informasi penting diperkenalkan sedini mungkin pada anak, baik dalam lingkungan keluarga dan sekolah dalam mendukung tahapan awal perkembangan anak dalam berinformasi dan berpengetahuan. Menkonstruksi pengalaman baru dari setiap aktivitas anak. Maka dari itu 
penyelenggaraan pendidikan anak usia dini baik formal maupun formal secara terkecuali harus juga memasukan keterampilan literasi informasi baik secara kuantitas maupun kualitas. Penambahan unsur literasi informasi dapat berperan sebagai cara agar anak dapat berpengetahuan secara mandiri sejak masa awal perkembangan. Sehingga ini akan menjadi jalan untuk anak dapat mengeksplorasi minat dan bakat atau menjadi sarana untuk peningkatan kecerdasan, bijaksana dan memiliki kepekaan sosial terhadap sesama.

Literasi budaya hakikatnya memuat pengetahuan dan pemahaman tentang budaya dapat berupa tradisi, kepercayaan, agama, kelompok etnik atau suku simbol dan ikon, termasuk juga sarana komunikasi sebuah negara dalam konteks informasi dan pengetahuan literasi budaya juga sangat berkaitan dengan penciptaan, penyimpanan, penggunaan, preservasi serta pengarsipan atas data dan pengetahuan dengan menggunakan teknologi. Pemahaman literasi informasi dalam kaitannya dengan literasi bdudaya adalah bagaimana faktor budaya berdampak terhadap penggunaan teknologi komunikasi dan informasi secara efisien. Dampak itu dapat positif maupun negatif.

\section{DAFTAR PUSTAKA}

Behrens, S. (1994). A Conceptual Analysis and Historical Review of Information Literacy. College and Research Libraries(55), 309-322.

Fairus, Naibaho, K., Monohevita, L., Aries, M., \& Pawoko, S. (2017). Literasi Informasi untuk Mahasiswa Baru Universitas Indonesia. Depok: Perpustakaan Universitas Indonesia.

Hapiro, J., \& Hughes, S. (1996). SInformation Literacy as a Liberal Art. Educom Review, 31-35.

Huberman, M., \& Miles, M. B. (2002). The qualitative researcher's companion. . Sage.

Owusu-Ansah, E. (2005). Debating Definitions of Information Literacy: Enough is Enough. Library Review, 54(6), 366-374.

Pusat Bahasa Departemen Pendidikan Nasional. (2007). Glosarium istilah asing - Indonesia.( Jakarta: Pusat Bahasa Departemen Pendidikan Nasional.

Riady, Y. (2013, Desember ). Literasi Informasi Sejak Dini: Pengetahuan Baru Bagi Anak Usia Dini. Jurnal Ilmiah VISI P2TK PAUDNI, 8(2), 159-165. 
Snavely, L., \& Cooper, N. (1997). The Information Literacy Debate. Journal of the Academic Librarianship, 23(1), 9-14.

Sulistyo-Basuki. (2011, Oktober 11). Literasi Informasi dan Literasi Digital. Diambil kembali dari https://sulistyobasuki.wordpress.com/: https://sulistyobasuki.wordpress.com/2013/03/25/literasi-informasi-danliterasi-digital/ 